\title{
Reproductive phenology of Mauritia flexuosa L. (Arecaceae) in a coastal restinga environment in northeastern Brazil
}

\author{
F. N. Mendes ${ }^{a *}$, R. M. Valente ${ }^{a}$, M. M. C. Rêgo ${ }^{b}$ and M. C. Esposito ${ }^{a}$ \\ a'Departamento de Biologia, Instituto de Ciências Biológicas, Universidade Federal do Pará - UFPA, \\ Av. Augusto Corrêa, 1, Guamá, CEP 66075-110, Belém, PA, Brazil \\ ${ }^{b}$ Laboratório de Estudos sobre Abelhas, Centro de Ciências Biológicas, Universidade Federal do Maranhão - UFMA, \\ Av. dos Portugueses, s/n, Bacanga, CEP 65085-580, São Luís, MA, Brazil \\ *e-mail: fnmodel@yahoo.com.br
}

Received: May 28, 2015 - Accepted: November 3, 2015 - Distributed: February 28, 2017

(With 2 figures)

\begin{abstract}
The buriti, Mauritia flexuosa, is the most common palm in Brazil, where it has considerable ecological and economic importance. However, few data are available on the phenology of the species, mainly in coastal restinga ecosystems. The present study monitored the reproductive phenology of M. flexuosa in the restinga of Barreirinhas, in the Brazilian Northeast, and investigated the relationship between phenophases and climatic variables. The presence/absence of flowers and fruits was recorded monthly in 25 individuals of each sex between August, 2009, and October, 2012. There was no difference in the phenology of male and female specimens, with flowering and fruiting occurring exclusively in the dry season. We believe that the specific abiotic characteristics of the study environment, such as the intense sunlight and availability of water in the soil, contribute to the reproductive success of $M$. flexuosa in the dry season, with consequent germination and establishment of seedlings occurring during the subsequent rainy season.
\end{abstract}

Keywords: buriti, ecology, Maranhão, palm tree.

\section{Fenologia reprodutiva de Mauritia flexuosa $\mathrm{L}$. (Arecaceae) em ambiente de Restinga no Nordeste do Brasil}

\begin{abstract}
Resumo
Popularmente conhecido como buriti, Mauritia flexuosa é a palmeira mais abundante no Brasil, com grande importância ecológica e econômica, porém ainda são poucos os estudos sobre a sua fenologia, não existindo nenhum em ambiente de Restinga. O presente trabalho teve como objetivo estudar a fenologia reprodutiva de M. flexuosa na Restinga de Barreirinhas, no Nordeste do Brasil, verificando como as fenofases se correlacionam com os fatores climáticos. Foram acompanhados mensalmente 25 indivíduos de cada sexo, de agosto/2009 a outubro/2012, verificando a presença/ausência de floração e frutificação. Não houve diferença no padrão fenológico entre indivíduos femininos e masculinos de $M$. flexuosa, com floração e queda dos frutos exclusivamente na estação seca. Acreditamos que as características abióticas específicas do ambiente estudado, como a forte incidência solar e a disponibilidade de água no solo, contribuíram para o sucesso reprodutivo de M. flexuosa na estação seca, com consequente germinação e estabelecimento de plântulas no período chuvoso.
\end{abstract}

Palavras-chave: buriti, ecologia, Maranhão, palmeira.

\section{Introduction}

Palms (Arecaceae) are a prominent component of most tropical ecosystems (Henderson et al., 1995), in which fruits constitute an important feeding resource for the local fauna (Peres, 1994; Galetti et al., 1999). In addition they are relevant to human populations, for which palms supply building material, foodstuffs, and ornamental plants (Silva and Andrade, 2005; Zambrana et al., 2007; Nascimento et al., 2010). Given their ecological and economic role, a number of studies in Brazil have focused

on the phenological patterns of palm species and the factors that influence these processes in the last decade (Calvi and Piña-Rodrigues, 2005; Piedade et al., 2006; Castro et al., 2007; Genini et al., 2009; Fava et al., 2011; Freire et al., 2013; Khorsand Rosa et al., 2013, 2014; Silva and Scariot, 2013; Guilherme et al., 2015).

Patterns of reproductive phenology may be influenced by a series of abiotic and biotic factors, such as rainfall, temperature, and day length (Van Schaik, 1986; Morellato et al., 
2000), the mode of dispersal (Wheelwright, 1985), and the activity of pollinators and seed dispersers (Rathcke and Lacey, 1985). Although climatic seasonality is probably the most important in the majority of cases (Wright and Van Schaik, 1994; Rivera and Borchert, 2001; Ruiz and Alencar, 2004). In tropical environments, especially where seasonal variation in rainfall is pronounced, the dry season typically determines phenological patterns, limiting plant growth and reproduction during this period (Reich and Borchert, 1984; Morellato et al., 1989).

In the specific case of palms, a number of studies have shown that flowering in tropical species is concentrated in one season, whereas non-tropical species may be observed flowering throughout the year (Steven et al., 1987; Ibarra-Manríquez, 1992). Considering a given species or genus, however, individual palms tend to flower only during a specific climatic season, with phenology being related primarily to pollinator abundance. Three distinct Neotropical groups can be defined here (Henderson et al., 2000) - palms pollinated by weevils (Curculionidae), with a short, highly synchronized flowering period (e.g., Astrocaryum G. Mey., Attalea Kunth, Bactris G. Mey., and Socratea $\mathrm{H}$. Karst.), palms pollinated by bees or flies, with a long, less synchronized period of flowering (e.g., Euterpe Mart., Geonoma Willd., and Hyospathe Mart.), and palms pollinated by beetles, with intermediate characteristics between those of the first two groups (e.g., Oenocarpus Mart. and Syagrus Mart.).

The buriti, Mauritia flexuosa L., is the most common palm species found in Brazil, observed in dense, monospecific stands (known locally as buritizais) primarily on flooded terrains adjacent to streams and rivers (Araújo et al., 2004). The species has considerable economic and ecological importance (Resende et al., 2012), and some data are available on the reproductive phenology of the species, although most studies have focused on Amazonian populations. In the Brazilian state of Amazonas, Storti (1993) recorded flowering at the end of the rainy season (April-August), whereas in the state of Roraima, in the northern Amazon basin, Khorsand Rosa et al. (2013) observed flowering between August and November, which represents the rainy-dry season transition period in this region. In a study of eight palm species in Bolivia, Cabrera and Wallace (2007) also recorded a peak of flowering in M. flexuosa during the rainy season. In Colombia, Núñez Avellaneda and Carreño Barrera (2013) observed peak of flowering between June and September, which represents also the rainy-dry season, but the flowers are present at any time of the year, with consequent presence of fruits throughout the year. The production of fruit may occur between eight and twelve months (Storti, 1993; Khorsand Rosa et al., 2013), with the fruits maturing during the rainy season (Peres, 1994; Calderón, 2002; Khorsand Rosa et al., 2013).

Restingas are coastal habitats located on sandy deposits (Cerqueira, 2000), formed by plant communities tolerant of marine and/or fluvial-marine influences (Sugiyama, 1998), with considerable variation in habitat characteristics, depending on the region in which they are found (Lacerda et al., 1984). Few ecological studies have focused on species of Arecaceae in restinga systems (Rosa et al., 1998; Menezes and Araújo, 2000, 2004; Reis, 2006), especially in the Brazilian Northeast. This is the first study of the reproductive phenology of M. flexuosa in this type of habitat. This long-term (four years) study evaluated three main questions: what is the phenological pattern of M. flexuosa in the restinga? Is there a difference between staminate and pistillate individuals? What environmental factors affect the phenology of M. Alexuosa in the study area?

\section{Material and Methods}

\subsection{Study area}

The present study was conducted on a private property in the Brazilian Northeast, Fazenda Buriti ( $2^{\circ} 43^{\prime}$ 07.23' S, $42^{\circ} 49^{\prime} 44.52^{\prime \prime} \mathrm{W}$ ), in the municipality of Barreirinhas, in the state of Maranhão (Figure 1). This ranch is located in the village of Cantinho, within the area of influence of the Lençóis Maranhenses National Park, the vegetation can be characterized as natural primary systems composed of pioneer communities, in particular restingas $(89.4 \%)$, a type of coastal vegetation generally associated with dune fields, saltwater mangroves $(10.2 \%)$, and freshwater gallery forests $(0.4 \%)$ (IBAMA, 2002).

The study population is a buritizal located in an area of low restinga forest (sensu Brasil, 1996), which has a sandy substrate and a shallow water table, which frequently leads to the formation of small temporary lakes (Figure 1). During the rainy season, this results in the flooding of the buriti stand, while the soil remains humid during the dry season.

The climate of the Barreirinhas region is tropical megathermic, consistent with Köppen's Aw' type, with annual precipitation of approximately $2000 \mathrm{~mm}$ and two well-defined seasons, a rainy season between January and June, and a dry season, between July and December (Figure 2). Mean annual temperatures are between $24^{\circ} \mathrm{C}$ and $34{ }^{\circ} \mathrm{C}$ (INMET, 2012).

\subsection{Data collection}

Phenological monitoring was conducted on a monthly basis between August, 2009, and October, 2012. A total of 25 staminate and 25 pistillate individuals were selected and marked along a trail of approximately $1 \mathrm{~km}$ in length. These specimens were selected based on three specific criteria: (i) adult specimens in reproductive condition, (ii) visibility of the crown adequate for the systematic observation of the phenophases, and (iii) a minimum distance of $20 \mathrm{~m}$ between specimens (Castro et al., 2007). The flowering (open flowers) and fruiting (mature and immature) phenophases were recorded using a pair of binoculars, with the presence or absence of each phase being recorded on a field checklist.

Flowering patterns were analyzed on individual and population levels, and described in terms of their frequency (number of cycles per year) and duration, i.e., the number of months (Newstrom et al., 1994). The synchronization of the phenophases was evaluated based on the proportion 


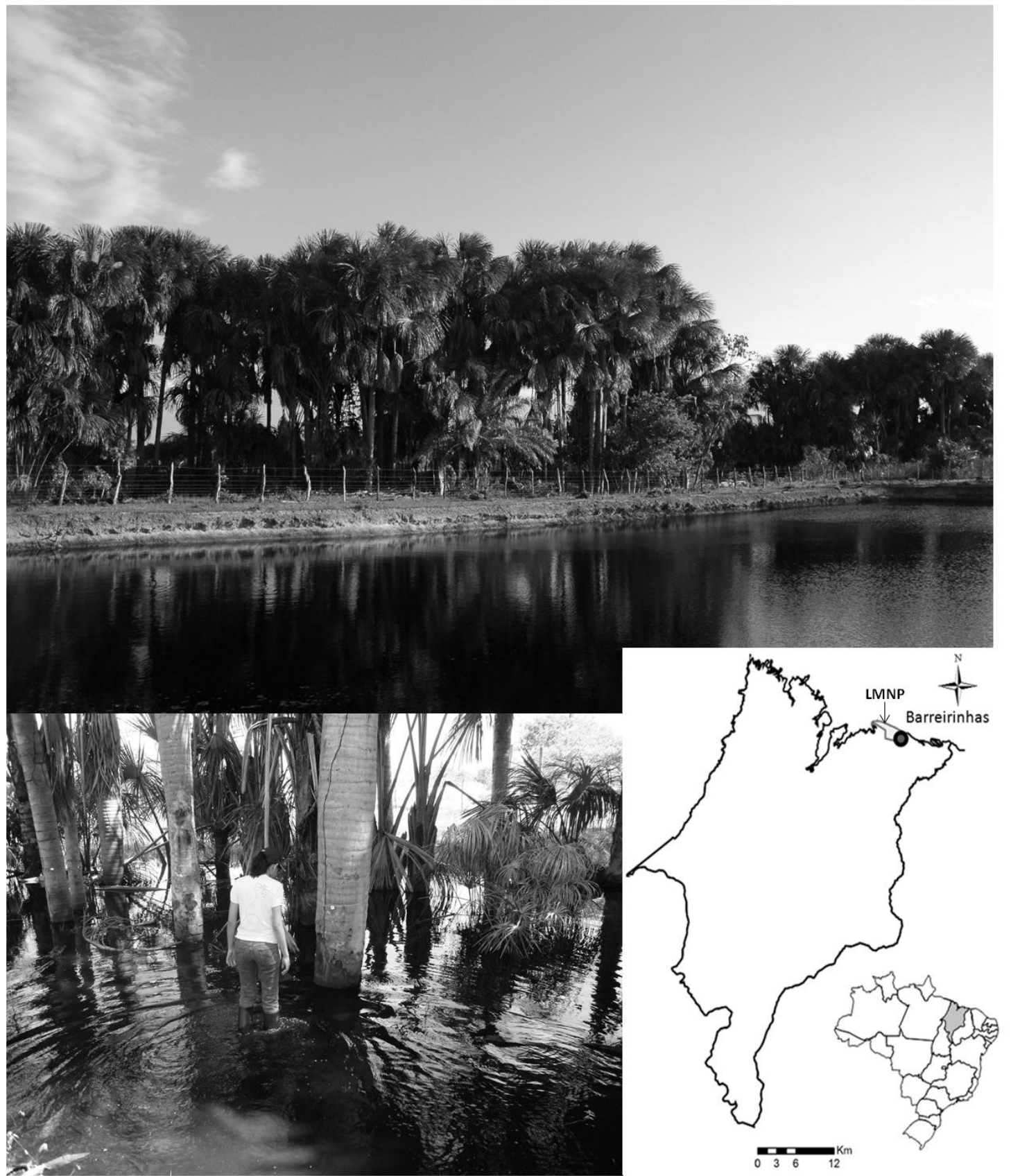

Figure 1. Location of the study area in the municipality of Barreirinhas, Maranhão (Brazil), showing the Lençóis Maranhenses National Park (LMNP).

of individuals presenting the same phenophase during a given period (Bencke and Morellato, 2002). Based on this, the phenological event was classified as non-synchronic or asynchronic when no more than $20 \%$ of the individuals presented the same phenophase, low synchrony when $21-60 \%$ of the individuals presented the same phenophase, and high synchrony when more than $60 \%$ of the individuals were in the same phase (Bencke and Morellato, 2002). Comparisons among years were based on the production of male and female reproductive structures in 20 individuals (10 pistillate and 10 staminate), based on the mean number of inflorescences per individual, and the mean number of rachilles, spikelets, and flowers per inflorescence.

Climatic data (mean, minimum and maximum temperatures, relative humidity, rainfall, and solar radiation) were obtained from the National Meteorological Institute's (INMET) Chapadinha meteorological station $\left(n^{\circ} 82,382\right)$. These potential influence of these variables on the phenology 


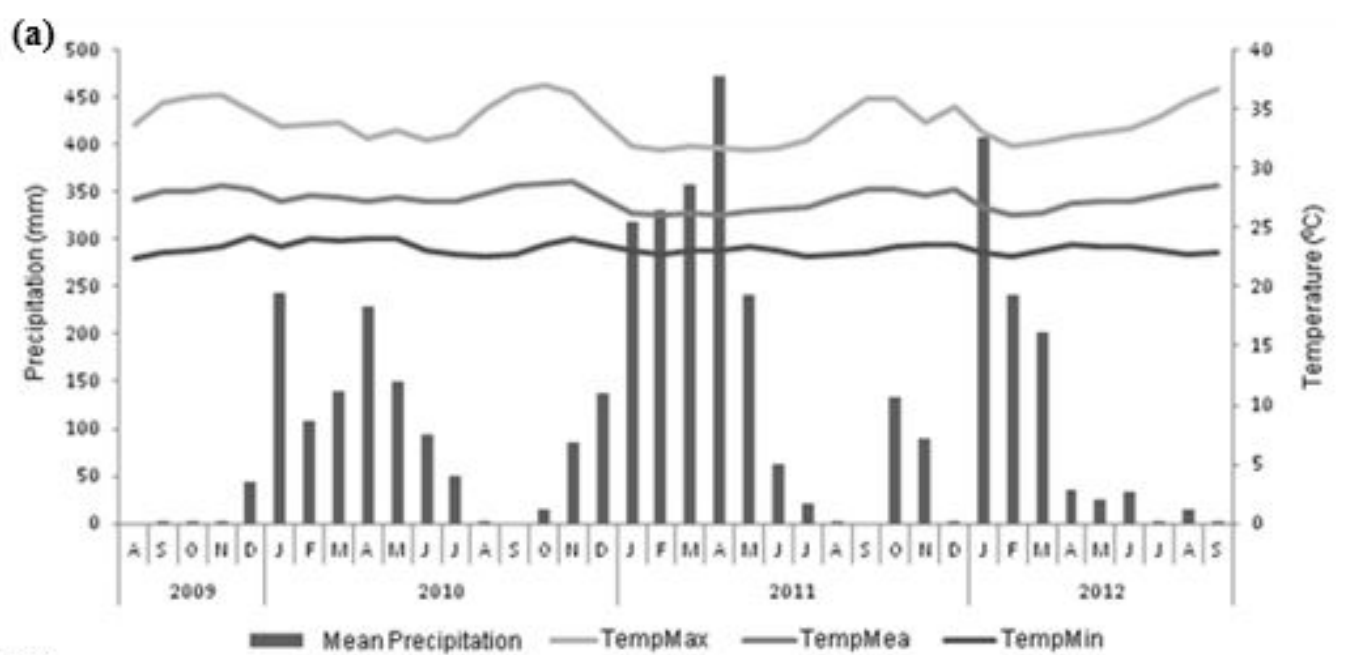

(b)

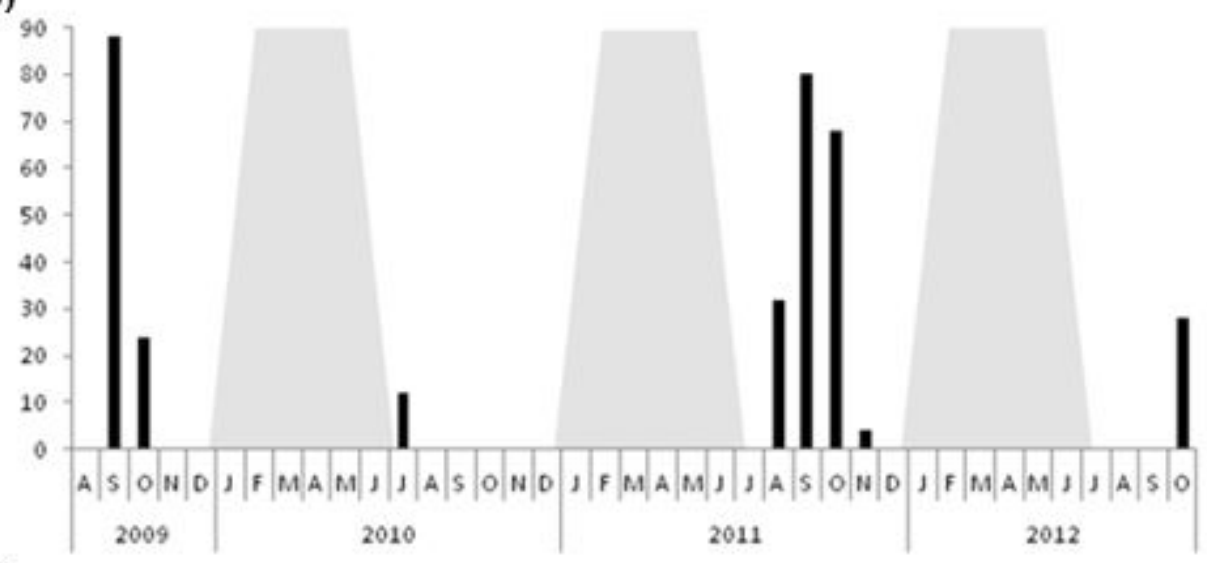

(c)

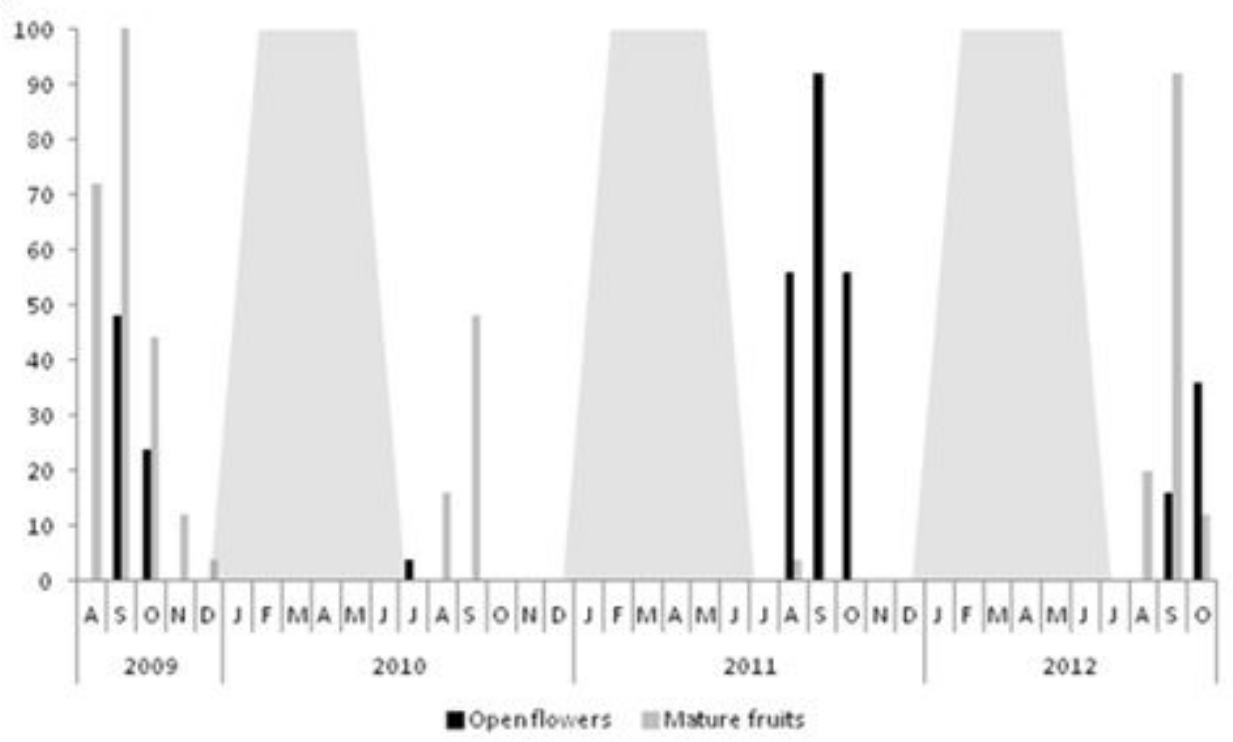

Figure 2. Climatic data and reproductive phenology of Mauritia flexuosa between August, 2009, and October, 2012, in Barreirinhas, Maranhão (Brazil): (a) mean monthly temperature and precipitation; (b) percentage of staminate individuals with open flowers; (c) percentage of pistillate individuals with open flowers and mature fruits. The shaded area represents the rainy season. 
of the species was evaluated using Spearman's correlation coefficient $\left(r_{s}\right)$, based on the number of individuals presenting each phenophase during a given month and the climatic variables recorded during both the same month and the preceding month (Marques et al., 2004).

\section{Results}

The study population of $M$. flexuos a flowered annually, with a high degree of synchrony among individuals, which present two different flowering strategies. The males produce flowers annually, while the females flower annually or every two years (super-annual). In both sexes, flowering occurred only during the dry season, with the flowers opening simultaneously in pistillate and staminate specimens.

While flowering occurred during the same period (between August and November) in each year of the study, some variation was recorded in the months, proportion of individuals flowering, and the duration of the flowering period (Figure 2). During the first year (2009), for example, $80 \%$ of the staminate and $48 \%$ of the pistillate individuals flowered in September (peak flowering month) and October. In the following year, flowering was only observed in July, and there was a considerable reduction in the number of individuals involved, with only $12 \%$ of the staminate and $4 \%$ of the pistillate individuals flowering. In the third year, flowering was more intense, with $92 \%$ of the staminate and $84 \%$ of the pistillate individuals flowering between August and November, with a peak in September. In the fourth year, the proportion of individuals flowering decreased again, to $36 \%$ (staminate) and $28 \%$ (pistillate) of the population, occurring between August and October, with a peak at the beginning of the latter month.

Fruiting was also synchronic, following a maturation period of 11 to 12 months, with mature fruits becoming available between August and December, that is, between the middle of the dry season and the beginning of the rainy season, with a peak in fruitfall in September (Figure 2). Over the four years of the study period, 10 individuals fruited in only one year, nine in two years, and six in three years, while none of the specimens fruited in all four years.

The mean time period between the formation of an inflorescence and the production of flowers was two to three months in both sexes. Between the first and the fourth years, a mean of four, three, five, and four inflorescences were produced per individual, with a range of three to $11($ mean $=5.8 \pm 3.3)$ in the staminate specimens, and three to nine $(6.8 \pm 1.9)$ in the pistillate individuals. Staminate palms produced a mean of 296,540 flowers, whereas pistillate individuals formed a mean of 3474 .

The Spearman correlation coefficients (Table 1) indicated significant relationships with the climatic variables solar radiation, relative humidity of the air, and precipitation, recorded during both the current month and the preceding month. Flowering was correlated positively with sunlight (both months) and negatively with minimum temperature (in the preceding month), relative humidity (both months), and rainfall in the preceding month. By contrast, the phenophase of the immature fruits did not correlate with any climatic variable, whereas the presence of mature fruit correlated significantly with all variables except the mean and maximum temperatures of the preceding month.

\section{Discussion}

The restinga population of $M$. flexuosa presented an annual flowering pattern, as observed in the Amazon basin by Storti (1993) and Khorsand Rosa et al. (2013). The duration of the flowering period (3-4 months) was intermediate, however, similar to that recorded by Khorsand Rosa et al. (2013), but shorter than the extended period of more than six months observed by Storti (1993). There were also differences in the mean number of reproductive structures produced by the species in the different ecosystems, with

Table 1. Spearman correlation coefficients $\left(r_{s}\right)$ recorded for the comparison of the phenophases of Mauritia flexuosa and the climate data recorded in a restinga ecosystem in Barreirinhas, Maranhão (Brazil).

\begin{tabular}{ccccc}
\hline \multirow{2}{*}{ Variable } & \multicolumn{4}{c}{ Phenophase } \\
\cline { 2 - 5 } TMax 0 & Staminate flower & Pistillate flower & Immature fruit & Mature fruit \\
TMax 1 & 0.30 & $\mathbf{0 . 3 9}$ & 0.07 & 0.55 \\
TMea 0 & 0.21 & 0.21 & 0.56 & 0.22 \\
TMea 1 & 0.25 & 0.31 & 0.04 & $\mathbf{0 . 4 9}$ \\
TMin 0 & 0.17 & 0.17 & 0.00 & 0.16 \\
TMin 1 & -0.21 & -0.30 & 0.01 & $\mathbf{0 . 3 8}$ \\
RH 0 & $\mathbf{- 0 . 3 9}$ & $\mathbf{- 0 . 4 7}$ & 0.01 & $-\mathbf{0 . 5 3}$ \\
RH 1 & $\mathbf{- 0 . 3 3}$ & $\mathbf{- 0 . 4 1}$ & -0.61 \\
Precip 0 & $\mathbf{- 0 . 3 5}$ & $\mathbf{- 0 . 4 0}$ & -0.01 & $\mathbf{- 0 . 4 1}$ \\
Precip 1 & -0.29 & $\mathbf{- 0 . 3 8}$ & -0.07 & $\mathbf{- 0 . 6 8}$ \\
Sol 0 & $\mathbf{- 0 . 4 4}$ & $\mathbf{- 0 . 5 0}$ & -0.07 & $\mathbf{- 0 . 4 4}$ \\
Sol 1 & $\mathbf{0 . 4 0}$ & $\mathbf{0 . 4 5}$ & 0.20 & $\mathbf{0 . 6 4}$ \\
\hline
\end{tabular}

TMax $=$ maximum temperature; TMea $=$ mean temperature; TMin $=$ minimum temperature; $\mathrm{RH}=$ relative humidity; Precip $=$ Precipitation; Sol $=$ solar radiation; $0=$ current month; $1=$ preceding month. Values in bold type are significant $(\mathrm{p}<0.05)$. 
$5.8(\delta)$ and 6.8() inflorescences being recorded per individual in the present study, against 4.7 ( $ぇ)$ and 4.8 (ㅇ) in the Amazon basin, and 292,540 ( $\delta$ ) and 3475 (ㅇ) flowers per individual, in contrast with 450,000 (ð) and 3612 ( 9 ) in the Amazon. Due the fact that a phenological event represents a physiological response to environmental factors (Fenner, 1998), it seems likely that a range of abiotic and/or biotic variables, characteristic of each ecosystem, have differential effects on the production of floral structures, and the phenological patterns of the same species in different ecosystems.

According to Núñez Avellaneda and Carreño Barrera (2013), patterns of flowering and fruiting of M. flexuosa are highly variable and change depending on the locality, and doesn't know yet if this variation is due to local environmental factors or is a consequence of the sampling method. In a review of the phenological data available for tropical plants, Van Schaik et al. (1993) demonstrated that abiotic factors tend to have the most important influence on phenological patterns. Solar radiation was identified as the most common factor, due to its influence on light and temperature, which influence primary production in plants (Van Schaik et al., 1993; Wright and Van Schaik, 1994). The phenophases of $M$. flexuosa correlated significantly with solar radiation, during both the current and the preceding months, indicating that this factor is of primary importance for the species reproduction. The species produces both flowers and fruits during the period of greatest solar radiation, that is, when solar energy peaks. Some studies have confirmed an increase in the frequency of flowering during periods of greater luminosity (Newstrom et al., 1994; Abrahamson, 1999), affecting palm species such as Orbignia phalerata Mart. and Socratea exorrhiza (Mart.) H. Wendl., which generally require high sunlight intensity to initiate growth (Scariot et al., 1989). Cunningham (1996) also observed that fruit production in the palm Calyptrogyne ghiesbreghtiana (Linden \& H. Wendl.) was influenced by the size of the plant and the availability of sunlight, reinforcing the importance of this resource in the development of the different phenophases.

The phenophases of $M$. flexuosa correlated negatively with precipitation in both months analyzed (current and preceding). Other hand, seasonal variation in rainfall can be an important factor for phenology (Reich and Borchert, 1984; Van Schaik et al., 1993). In the study area, total annual rainfall fluctuated considerably among years. In the second year (2010), total rainfall was greatly reduced in comparison to the other years and only $12 \%$ of the staminate and $4 \%$ of the pistillate individuals flowered. By contrast, during the third year, the highest rainfall level was recorded $(2031 \mathrm{~mm})$, and the highest proportion of individuals flowered ( $92 \%$ staminate and $84 \%$ pistillate). So rainfall must be important for the maintenance of groundwater levels, given that the water table is just below the surface, and must contain a sufficient supply of water to guarantee the production of reproductive structures in the buriti palms, independently of the season. These data corroborate with the findings of Khorsand Rosa et al.
(2014), which determined that abiotic factors that most significantly affected fruit and seed output were soil moisture and flooding during the wet season. Khorsand Rosa et al. (2013) observed flowering in M. flexuosa in the rainy/dry season transition, and that the process was associated negatively with the precipitation during the current month, but positively with the rainfall over the previous three months, and concluded that flowering may represent a delayed response to rainfall levels, with the end of the rainy season, a few months prior to the flowering period, appearing to be one of the principal determinants of flowering in this species, a pattern also observed in a number of other tropical tree species (McLaren and McDonald, 2005). This appears to account for the restriction of the flowering of $M$. flexuosa to the dry season in the restinga, in contrast with the pattern observed in Amazonas (Storti, 1993) and the Bolivian Amazon (Cabrera and Wallace, 2007), where the species only flowered during the rainy season.

Flowering peaks during the dry (or less rainy) season have also been recorded in other tropical palms, such as Attalea oleifera Barb. Rodr. (Locatelli and Machado, 2004), A. phalerata Mart. ex. Spreng (Cabrera and Wallace, 2007), Butia purpurascens Glassman (Guilherme et al., 2015), Cocos nucifera L. (Leite and Encarnação, 2002), and Oenocarpus bataua Mart. (Ruiz and Alencar, 2004). One variable that may account for this phenomenon is the fact that the number of pollinators tends to be greater during the dry season, due to the more favorable conditions for this activity, which would contribute to the success of the pollination process (Janzen, 1967; Van Schaik et al., 1993; Bendix et al., 2006). During the rainy season, by contrast, the performance of pollinators may be limited by the intense and prolonged rains, in addition to an increase in the potential for physical damage to the flowers and the loss of a large proportion of the pollen grains (Fisch et al., 2000; Martén and Quesada, 2001).

In the present study, an annual and synchronic pattern of fruiting was also observed, with the individuals producing fruits annually or supra-annually (in alternating years), with considerable variation among years in productivity. In the Amazon, Storti (1993) recorded fruiting in M. flexuosa every two years, that is, a supra-annual pattern in the terminology of Newstrom et al. (1994). Calderón (2002) recorded $M$. flexuosa flowering and fruiting every year, but without synchrony among individuals, and females that had produced a large quantity of fruit in one year (as many as six infructescences), would produce only one or two, or sometimes no inflorescences whatsoever in the following year. This reproductive pattern may be closely related to the quantity of energy fixed by the plant (Calderón, 2002) and nutrients available in the soil (Pedroni et al., 2002), independently of the results of previous fruiting bouts. A similar pattern has been observed in other palms, such as Acrocomia aculeata (Jacq.) Lodd. ex. Mart. (Scariot et al., 1995), Butia capitata (Mart.) Becc. (Rosa et al., 1998), Euterpe edulis Mart. (Fisch et al., 2000), and E. oleraceae Mart. (Jardim and Kageyama, 1994). 
In addition, major fluctuations in fruit productivity among years - mast fruiting - may be important to seed predator's population control (Rathcke and Lacey, 1985; Calderón, 2002; Santos and Takaki, 2005). Mast fruiting in $M$. flexuosa may not only permit the avoidance of predation through the excessive satiation of predators, but also contribute to an increase in visitation by potential dispersers (Van Schaik et al., 1993; Pedroni et al., 2002; Santos and Takaki, 2005).

In the Amazon region, the highest rates of fruitfall were recorded in M. flexuosa during the rainy season, in Bolivia (Cabrera and Wallace, 2007), Venezuela (Calderón, 2002), and Roraima, Brazil (Khorsand Rosa et al., 2013). In the swamps of the eastern and central Amazon basin, however, the fruiting peak may coincide with the dry season (Cavalcante, 1974), as observed in the present study, in the restinga of eastern Maranhão. It seems reasonable to assume that the availability of groundwater in these environments means that water is not a limiting factor, and that these populations of M. flexuosa do not depend on the increased precipitation of the rainy season to reproduce. In these environments, the maturation and fall of fruits during the dry season may be advantageous to the palm, given the increased possibility of seed germination during the subsequent rainy season, when conditions will be ideal for the germination of the seeds of a wide variety of plants (Felfili et al., 1999; Khorsand Rosa et al., 2013), in addition to an increased probability of dispersal by frugivores, given that the fruits of M. flexuosa represent a key resource during the dry season, when most other resources are relatively scarce, provoking an increase in intra- and inter-specific competition (Steven et al., 1987; Wallace and Painter, 2002; Cabrera and Wallace, 2007).

\section{Acknowledgements}

We are grateful to Manuel Nascimento for permission to conduct this study on his property, and to Manoel Rocha and Heriberto Figueira da Silva Filho for their assistance in the field. We also thank the Brazilian National Research Council (CNPq) for financing the project and the doctoral stipend conceded to the first author, and the Brazilian Higher Education Training Program (CAPES) for the sandwich grant provided to the first author.

\section{References}

ABRAHAMSON, W.G., 1999. Episodic reproduction in two fireprone palms, Serenoa repens and Sabal etonia (Palmae). Ecology, vol. 80, no. 1, pp. 100-115. http://dx.doi.org/10.2307/176982.

ARAÚJO, J.R.G., MARTINS, M.R. and SANTOS, F.N., 2004. Fruteiras nativas: ocorrência e potencial de utilização na agricultura familiar do Maranhão. In: E.G. MOURA. Agroambientes de transição entre o trópico úmido e semi-árido do Brasil: atributos, alterações e uso na agricultura familiar. São Luís: Universidade Estadual do Maranhão, pp. 257-312.

BENCKE, C.S. and MORELLATO, L.P.C., 2002. Estudo comparativo da fenologia de nove espécies arbóreas em três tipos de floresta atlântica no Sudeste do Brasil. Revista Brasileira de Botânica, vol. 25, no. 2, pp. 237-248. http://dx.doi.org/10.1590/ S0100-84042002000200012.

BENDIX, J., HOMEIER, J., CUEVA ORTIZ, E., EMCK, P., BRECKLE, S.-W., RICHTER, M. and BECK, E., 2006. Seasonality of weather and tree phenology in a tropical evergreen mountain rain forest. International Journal of Biometeorology, vol. 50, no. 6, pp. 370-384. http://dx.doi.org/10.1007/s00484-006-0029-8. PMid:16598482.

BRASIL. Conselho Nacional do Meio Ambiente - CONAMA, 1996. Resolução $n^{\circ}$ 07/96, de 23 de julho de 1996. Anexo da Resolução CONAMA $n^{\circ}$ 07/96. Diário Oficial da República Federativa do Brasil, Brasília, 26 ago.

CABRERA, W.H. and WALLACE, R., 2007. Patrones fenológicos de ocho especies de palmeras en um bosque amazónico de Bolivia. Revista Boliviana de Ecología y Conservación Ambiental, vol. 21, pp. 1-18.

CALDERÓN, M.E.P., 2002. Patrones de caída de frutos em Mauritia fexuosa 1. f. y fauna involucrada em los procesos de remoción de semillas. Acta Botanica Venezuelica, vol. 25, no. 2, pp. 119-142.

CALVI, G.P. and PIÑA-RODRIGUES, F.C.M., 2005. Fenologia e produção de sementes de Euterpe edulis - Mart em trecho de floresta de altitude no município de Miguel Pereira-RJ. Revista Universidade Rural, vol. 25, no. 1, pp. 33-40.

CASTRO, E.R., GALETTI, M. and MORELLATO, L.P.C., 2007. Reproductive phenology of Euterpe edulis (Arecaceae) along a gradient in the Atlantic rain forest of Brazil. Australian Journal of Botany, vol. 55, no. 7, pp. 725-735. http://dx.doi. org/10.1071/BT07029.

CAVALCANTE, P.B., 1974. Frutas comestiveis da Amazônia. 1st ed. Belém: Museu Paraense Emílio Goeldi. 73 p.

CERQUEIRA, R., 2000. Biogeografia das restingas. In: ESTEVES, F.A. and LACERDA, L.D., eds. Ecologia de restingas e lagoas costeiras. Rio de Janeiro: Núcleo de Pesquisas Ecológicas de Macaé, Universidade Federal do Rio de Janeiro, pp. 65-75.

CUNNINGHAM, S.A., 1996. Pollen supply limits fruit initiation by a rain forest understorey palm. Journal of Ecology, vol. 84, no. 2, pp. 185-194. http://dx.doi.org/10.2307/2261354.

FAVA, W.S., COVRE, W.S. and SIGRIST, M.R., 2011. Attalea phalerata and Bactris glaucescens (Arecaceae, Arecoideae): Phenology and pollination ecology in the Pantanal, Brazil. Flora, vol. 206, no. 6, pp. 575-584. http://dx.doi.org/10.1016/j. flora.2011.02.001.

FELFILI, J.M., SILVA-JUNIOR, M.C., DIAS, B.J. and REZENDE, A.V., 1999. Estudo fenológico de Stryphnodendron adstringens (Mart.) Coville no cerrado sensu stricto da Fazenda Água Limpa no Distrito Federal, Brasil. Revista Brasileira de Botânica, vol. 22, no. 1, pp. 83-90. http://dx.doi.org/10.1590/ S0100-84041999000100011.

FENNER, M., 1998. The phenology of growth and reproduction in plants. Perspectives in Plant Ecology, Evolution and Systematics, vol. 1, no. 1, pp. 78-91. http://dx.doi.org/10.1078/1433-8319-00053.

FISCH, S.T.V., NOGUEIRA, J.R.L.R. and MANTOVANI, W., 2000. Fenologia reprodutiva de Euterpe edulis Mart. na Mata Atlântica (Reserva Biológica do Trabiju, Pindamonhangaba - SP). Revista Biociências, vol. 6, no. 2, pp. 31-37. 
FREIRE, C.C., CLOSEL, M.B., HASUI, E. and RAMOS, F.N., 2013. Reproductive phenology, seed dispersal and seed predation in Syagrus romanzoffiana in a highly fragmented landscape. Annales Botanici Fennici, vol. 50, no. 4, pp. 220-228. http:// dx.doi.org/10.5735/086.050.0403.

GALETTI, M., ZIPARRO, V.B. and MORELLATO, P.C., 1999. Fruiting phenology and frugivory on the palm Euterpe edulis in a lowland atlantic forest of Brazil. Ecotropica, vol. 5, pp. 115-122.

GENINI, J., GALETTI, M. and MORELLATO, P.C., 2009. Fruiting phenology of palms and trees in an Atlantic rainforest land-bridge island. Flora, vol. 204, no. 2, pp. 131-145. http:// dx.doi.org/10.1016/j.flora.2008.01.002.

GUILHERME, F.A.G., VASCONCELOS, E.I., COELHO, C.P., RESSEL, K., BATISTA, N.T.F. and SOUZA, L.F., 2015. Vegetative and reproductive phenology of Butia purpurascens Glassman (Arecaceae) under the effects of leaf harvesting. Brazilian Journal of Biology = Revista Brasileira de Biologia, vol. 75, no. 1, pp. 7785. http://dx.doi.org/10.1590/1519-6984.07513. PMid:25945623.

HENDERSON, A., FISCHER, B., SCARIOT, A., PACHECO, M.A.W. and PARDINI, R., 2000. Flowering phenology of a palm community in a central amazon forest. Brittonia, vol. 52, no. 2, pp. 149-159. http://dx.doi.org/10.2307/2666506.

HENDERSON, A., GALEANO, G. and BERNAL, R., 1995. Field guide to the palms of the Americas. New Jersey: Princeton University Press. 352 p.

IBARRA-MANRÍQUEZ, G., 1992. Fenología de las palmas de una selva cálido húmeda de México. Bulletin de I'Institut Français d'Etudes Andines, vol. 21, no. 2, pp. 669-693.

INSTITUTO BRASILEIRO DE MEIO AMBIENTE E DOS RECURSOS NATURAIS RENOVÁVEIS - IBAMA, 2002. Plano de manejo do Parque Nacional dos Lençóis Maranhenses - MA. São Luís: IBAMA.

INSTITUTO NACIONAL DE METEOROLOGIA - INMET [online], 2012 [viewed 15 Nov 2012]. Available from: http:// www.inmet.gov.br

JANZEN, D.H., 1967. Synchronization of sexual reproduction of trees within dry season in Central America. Evolution: International Journal of Organic Evolution, vol. 21, no. 3, pp. 620-637. http:// dx.doi.org/10.2307/2406621.

JARDIM, M A.G. and KAGEYAMA, P.Y., 1994. Fenologia de floração e frutificação em população natural de açaizeiro (Euterpe oleraceae Mart.) no estuário amazônico. Piracicaba: Instituto de Pesquisas e Estudos Florestais, vol. 47, pp. 62-65.

KHORSAND ROSA, R., BARBOSA, R.I. and KOPTUR, S., 2013. How do habitat and climate variation affect phenology of the Amazonian palm, Mauritia flexuosa? Journal of Tropical Ecology, vol. 29, no. 3, pp. 255-259. http://dx.doi.org/10.1017/ S0266467413000242.

KHORSAND ROSA, R., BARBOSA, R.I. and KOPTUR, S., 2014. Which factors explain reproductive output of Mauritia flexuosa (Arecaceae) in forest and savanna habitats of Northern Amazon? International Journal of Plant Sciences, vol. 175, no. 3, pp. 307-318. http://dx.doi.org/10.1086/674446.

LACERDA, L.D., ARAÚJO, D.S.D., CERQUEIRA, R. and RUCQ, B., 1984. Restinga: origem, estrutura e processos. Niterói: CEUFF.

LEITE, I.R. and ENCARNAÇÃO, C.R.F., 2002. Fenologia do coqueiro na zona costeira de Pernambuco. Pesquisa Agropecuaria
Brasileira, vol. 37, no. 6, pp. 745-752. http://dx.doi.org/10.1590/ S0100-204X2002000600002.

LOCATELLI, E. and MACHADO, I.C., 2004. Fenologia das espécies arbóreas de uma mata serrana (Brejo de Altitude) em Pernambuco, Nordeste do Brasil. In: K.C. PÔRTO, J.J. CABRAL and M. TABARELLI. Brejos de Altitude: história natural, ecologia e conservação. Brasília: MMA/PROBIO, pp. 255-276.

MARQUES, M.C.M., ROPER, J.J. and SALVALAGGIO, A.P.B., 2004. Phenological patterns among plant life-forms in a subtropical forest in southern Brazil. Plant Ecology, vol. 173, no. 2, pp. 202213. http://dx.doi.org/10.1023/B:VEGE.0000029325.85031.90.

MARTÉN, S. and QUESADA, M., 2001. Phenology, sexual expression, and reproductive success of the rare neotropical palm Geonoma epetiolata. Biotropica, vol. 33, no. 4, pp. 596-605. http:// dx.doi.org/10.1111/j.1744-7429.2001.tb00218.x.

MCLAREN, K.P. and MCDONALD, M.A., 2005. Seasonal patterns of flowering and fruiting in a dry tropical forest in Jamaica. Biotropica, vol. 37, no. 4, pp. 584-590. http://dx.doi. org/10.1111/j.1744-7429.2005.00075.x.

MENEZES, L.F. and ARAUJO, D.S.D., 2000. Variação da biomassa aérea de Allagoptera arenaria (Gomes) O. Kuntze (Arecaceae) em uma comunidade arbustiva de Palmae na restinga de Marambaia, RJ. Brazilian Journal of Biology = Revista Brasileira de Biologia, vol. 60 , no. 1 , pp. 147-157. http://dx.doi.org/10.1590/S003471082000000100017. PMid:10838933.

MENEZES, L.F. and ARAUJO, D.S.D., 2004. Regeneração e riqueza da formação arbustiva de Palmae em uma cronosequência pós-fogo na Restinga da Marambaia, Rio de Janeiro, RJ, Brasil. Acta Botanica Brasílica, vol. 18, no. 4, pp. 771-780. http://dx.doi. org/10.1590/S0102-33062004000400007.

MORELLATO, L.P.C., RODRIGUES, R.R., LEITÃO FILHO, H.F. and JOLY, C.A., 1989. Estudo comparativo de espécies arbóreas de Floresta de Altitude e Floresta Mesófila Semidecídua na Serra do Japi, Jundiaí, São Paulo. Revista Brasileira de Botânica, vol. 12, no. 2, pp. 85-98. http://dx.doi.org/10.1590/ S0100-84042002000200012.

MORELLATO, L.P.C., TALORA, D.C., TAKAHASI, A., BENCKE, C.C., ROMERA, E.C. and ZIPPARRO, V.B., 2000. Phenology of Atlantic Rain Forest trees: a comparative study. Biotropica, vol. 32, no. 4b, pp. 811-823. http://dx.doi.org/10.1111/j.1744-7429.2000. tb00620.x

NASCIMENTO, A.R.T., SANTOS, A.A. and DIAS, T.A.B., 2010. Riqueza e etnobotânica de palmeiras no território indígena Krahó, Tocatins, Brasil. Floresta, vol. 40, no. 1, pp. 209-220. http://dx.doi.org/10.5380/rf.v40i1.17112.

NEWSTROM, L.E., FRANKIE, G.W. and BAKER, H.G., 1994. A new classification for plant phenology based in flowering patterns in lowland tropical rain forest trees at La Selva, Costa Rica. Biotropica, vol. 26, no. 2, pp. 141-159. http://dx.doi. org/10.2307/2388804

NÚÑEZ AVELLANEDA, L.A. and CARREÑO BARRERA, J., 2013. Biología reproductiva de Mauritia flexuosa en Casanare, Orinoquia colombiana. In: C.A. LASSO, A. RIAL and V. GONZÁLEZ-B. Morichales y cananguchales de la Orinoquia y Amazonia: Colombia-Venezuela. Parte I. Bogotá: Instituto de Investigación de Recursos Biológicos Alexander von Humboldt, pp. $119-150$

PEDRONI, F., SANCHEZ, M. and SANTOS, F.A.M., 2002. Fenologia da copaíba (Copaifera langsdorffii Desf. - Leguminosae, 
Caesalpiniodeae) em uma floresta semidecídua no sudeste do Brasil. Revista Brasileira de Botânica, vol. 25, no. 2, pp. 183-194. http://dx.doi.org/10.1590/S0100-84042002000200007.

PERES, C.A., 1994. Composition, density, and fruiting phenology of arborescent palms in an Amazonian Terra Firme forest. Biotropica, vol. 26, no. 3, pp. 285-294. http://dx.doi.org/10.2307/2388849.

PIEDADE, M.T.F., PAROLIN, P. and JUNK, W.J., 2006. Phenology, fruit production and seed dispersal os Astrocaryum jauari (Arecaceae) in Amazonian black water foodplains. Revista de Biologia Tropical, vol. 54, no. 4, pp. 1171-1178. http://dx.doi. org/10.15517/rbt.v54i4.14099. PMid:18457155.

RATHCKE, B. and LACEY, E.P., 1985. Phenological patterns of terrestrial plants. Annual Review of Ecology and Systematics, vol. 16 , no. 1, pp. 179-214. http://dx.doi.org/10.1146/annurev. es.16.110185.001143.

REICH, P.B. and BORCHERT, R., 1984. Water stress and tree phenology in a tropical dry forest in the lowlands of Costa Rica. Journal of Ecology, vol. 72, no. 1, pp. 61-74. http://dx.doi. org/10.2307/2260006.

REIS, R.C.C., 2006. Palmeiras (Arecaceae) das restingas do Estado do Rio de Janeiro, Brasil. Acta Botanica Brasílica, vol. 20, no. 3, pp. 501-512. http://dx.doi.org/10.1590/S0102-33062006000300001.

RESENDE, I.L.M., SANTOS, F.P., CHAVES, L.J. and NASCIMENTO, J.L., 2012. Estrutura etária de populações de Mauritia flexuosa L. F. (Arecaceae) de veredas da região central de Goiás, Brasil. Revista Árvore, vol. 36, no. 1, pp. 103-112. http:// dx.doi.org/10.1590/S0100-67622012000100012.

RIVERA, G. and BORCHERT, R., 2001. Induction of flowering in tropical trees by a 30-min reduction in photoperiod: evidence from field observations and herbarium specimens. Tree Physiology, vol. 21, no. 4, pp. 201-212. http://dx.doi.org/10.1093/treephys/21.4.201. PMid:11276414.

ROSA, L., CASTELLANI, T.T. and REIS, A., 1998. Biologia reprodutiva de Butia capitata (Martius) Beccari var. odorata (Palmae) na restinga do município de Laguna, SC. Revista Brasileira de Botânica, vol. 21, no. 3, pp. 281-287. http://dx.doi. org/10.1590/S0100-84041998000300007.

RUIZ, R.R. and ALENCAR, J.C., 2004 Comportamento fenológico da palmeira patauá (Oenocarpus bataua) na reserva florestal Adolpho Ducke, Manaus, Amazonas, Brasil. Acta Amazonica, vol. 34, no. 4, pp. 553-558. http://dx.doi.org/10.1590/S004459672004000400007.

SANTOS, D.L. and TAKAKI, M., 2005. Fenologia de Cedrela fissilis Vell. (Meliceae) na região rural de Itirapina, SP, Brasil. Acta Botanica Brasílica, vol. 19, no. 3, pp. 625-632. http://dx.doi. org/10.1590/S0102-33062005000300024.

SCARIOT, A., LLERAS, E. and HAY, J.D., 1995. Flowering and fruiting phenologies of the palm Acrocomia aculeata: patterns and consequences. Biotropica, vol. 27, no. 2, pp. 168-173. http:// dx.doi.org/10.2307/2388992.
SCARIOT, A.O., OLIVEIRA FILHO, A.T. and LLERAS, E., 1989. Species richness, density and distribution of palms in eastern Amazonian seasonally flooded forest. Principes, vol. 33, no. 4, pp. 172-179.

SILVA, A.J. and ANDRADE, L.H.C., 2005. Etnobotânica nordestina: estudo comparativo da relação entre comunidades e vegetação na Zona do Litoral - Mata do Estado de Pernambuco, Brasil. Acta Botanica Brasílica, vol. 19, no. 1, pp. 45-60. http:// dx.doi.org/10.1590/S0102-33062005000100006.

SILVA, P.A. and SCARIOT, A., 2013. Phenology, biometric parameters and productivity of fruits of the palm Butia capitata (Mart.) Beccari in the Brazilian cerrado in the north of the state of Minas Gerais. Acta Botanica Brasílica, vol. 27, no. 3, pp. 580-589. http://dx.doi.org/10.1590/S0102-33062013000300015.

STEVEN, D.D., WINDSOR, D.M., PUTZ, F.E. and DE LEON, B., 1987. Vegetative and reproductive phenologies of a palm assemblage in Panama. Biotropica, vol. 19, no. 4, pp. 342-356. http://dx.doi.org/10.2307/2388632.

STORTI, E.F., 1993. Biologia floral de Mauritia flexuosa Lin. Fil., na Região de Manaus, AM, Brasil. Acta Amazonica, vol. 23, no. 4, pp. 371-381. http://dx.doi.org/10.1590/1809-43921993234381.

SUGIYAMA, M., 1998. Estudo de florestas da restinga da Ilha do Cardoso, Cananéia, São Paulo, Brasil. Boletim do Instituto de Botânica, vol. 11, pp. 119-159.

VAN SCHAIK, C.P., 1986. Phenological changes in a Sumatran rain forest. Journal of Tropical Ecology, vol. 2, no. 4, pp. 327-347. http://dx.doi.org/10.1017/S0266467400000973.

VAN SCHAIK, C.P., TERBORGH, J.W. and WRIGHT, S.J., 1993. The phenology of tropical forests: adaptative significance and consequences for primary consumers. Annual Review of Ecology and Systematics, vol. 24, no. 1, pp. 353-377. http:// dx.doi.org/10.1146/annurev.es.24.110193.002033.

WALLACE, R.B. and PAINTER, R.L.E., 2002. Phenological patterns in a southern Amazonian tropical forest: implication for sustainable management. Forest Ecology and Management, vol. 160, no. 1-3, pp. 19-33. http://dx.doi.org/10.1016/S03781127(00)00723-4.

WHEELWRIGHT, N.T., 1985. Competition for dispersers, and the time of flowering and fruiting in a guild of tropical trees. Oikos, vol. 44, no. 3, pp. 465-477. http://dx.doi.org/10.2307/3565788.

WRIGHT, S.J. and VAN SCHAIK, C.P., 1994. Light and the phenology of tropical trees. American Naturalist, vol. 143, no. 1, pp. 193-199. http://dx.doi.org/10.1086/285600.

ZAMBRANA, N.Y.P., BYG, A., SVENNING, J.-C., MORAES, M., GRANDEZ, C. and BALSLEV, H., 2007. Diversity of palm uses in the western Amazon. Biodiversity and Conservation, vol. 16, no. 10, pp. 2771-2787. http://dx.doi.org/10.1007/s10531007-9218-y. 